\title{
SELF-OWNERSHIP AND THE IMPORTANCE OF THE HUMAN BODY*
}

\author{
By IAN CARTER
}

\begin{abstract}
In this essay I attempt to vindicate the "asymmetry thesis," according to which ownership of one's own body is intrinsically different from ownership of other objects, and the view that self-ownership, as libertarians normally understand the concept, enjoys a special "fact-insensitive" status as a fundamental right. In particular, I argue in favor of the following claims. First, the right of self-ownership is most plausibly understood as based on the more fundamental notion of respect for persons, where the concept of a person is in turn understood, along the lines set out by P. F. Strawson and P. M. S. Hacker, as referring to an entire biological organism with a certain set of mental and corporeal characteristics. If we restrict our attention to human persons, we can say on this basis that there is a special moral status attaching to the entire human body, and to no more than the human body. Second, self-ownership is not, as critics have sometimes supposed, based on a more fundamental right to equal freedom or autonomy. Criticisms of self-ownership as insufficiently justified on the basis of such rights are therefore off target. Rather, equal freedom and self-ownership are each based directly on the more fundamental notion of respect for persons. For left-libertarians, the asymmetry thesis serves to give priority to self-ownership when delineating a set of original property rights, given that there are many alternative ways of realizing equal freedom not all of which involve fully respecting people's property rights in themselves.
\end{abstract}

KEY WORDS: self-ownership, personhood, self, human body, autonomy, freedom, left-libertarianism, P. F. Strawson, P. M. S. Hacker, respect for persons, rights, property

\section{INTRODUCTION}

Is my body a special kind of object? Advocates of self-ownership are intuitively drawn to this idea: my body is different, in an ethically relevant way, from my car; and the screwdriver I'm holding isn't the same kind of object as the hand that's holding it. Why? Because I am the body in question, the hand is a part of $m e$, whereas the car and the screwdriver, however useful to me, are not. The fact that I am a human body gives us a prima facie reason for thinking that my basic rights must include those of using and disposing of that body without unwanted interference by others.

* For helpful comments on earlier drafts of this essay I am grateful to Emanuela Ceva, Corrado Fumagalli, Pietro Intropi, Matthew Kramer, Fulvio Miceli, Valeria Ottonelli, Hillel Steiner, Laura Valentini, and Peter Vallentyne, as well as to the other contributors to this volume and to participants in the University of Milan Political Philosophy Brown Bag Seminar. I completed this essay while holding a By-Fellowship at Churchill College, Cambridge. I am grateful to the College, and to the Cambridge Forum for Legal and Political Philosophy, for their support. 
But this view of the body, as being ethically special in a way that clarifies the nature of our basic rights, has come under attack from several quarters. Egalitarian critics of self-ownership have argued that the view stands in need of justification by reference to some more basic moral premise about what is owed to persons. Such premises might include the equal right of all persons to freedom or autonomy or the means to leading a minimally flourishing life. But once the real implications of these more basic premises are clarified, the critics claim, it will no longer be obvious that self-ownership is entailed. For example, if we try to base selfownership on the requirements of a minimally flourishing life, we will see that a person's need for certain external resources, such as a car or a kidney machine, might be greater than her need to control certain specific parts of her own body, and that some people might indeed need parts of other people's bodies. Or if we appeal to the principle of equal freedom, we might find that such a principle is just as well respected if each person is given control over someone else's right arm and lacks control over her own right arm, or if various uses of one's own body are prohibited for everyone in order to protect other liberties for everyone. ${ }^{1}$

These skeptical views represent a challenge to what Kasper LippertRasmussen has called the asymmetry thesis, according to which "ownership of external resources is intrinsically different, morally, from ownership of one's mind and body." ${ }^{2}$ For those who share Lippert-Rasmussen's skepticism about the asymmetry thesis, the human body is just one resource among many. I have a human body in the same way as I can have a car or a kidney machine. All such things can be useful in pursuing our ends, achieving autonomy, leading a minimally flourishing life, and so on, and while the human body is certainly a very important resource, other resources can be very important too. The human body does not have a special status as a matter of principle. In the words of Cécile Fabre, "at the bar of justice, material resources and body parts are relevantly analogous." 3

One way in which Lippert-Rasmussen attempts to undermine the asymmetry thesis is by arguing that self-ownership is at best a "fact-sensitive" principle. If self-ownership is a fact-sensitive principle, then it derives from certain basic moral premises only in light of certain contingent facts about the world-for example, facts about how we relate to our bodies

\footnotetext{
${ }^{1}$ For critiques of self-ownership based on freedom or autonomy see: Alan Ryan, "SelfOwnership, Autonomy, and Property Rights," Social Philosophy and Policy 11, no. 2 (1994): 241-58; G. A. Cohen, Self-Ownership, Freedom, and Equality (Cambridge: Cambridge University Press, 1995), 97-102, 236-44; George B. Brenkert, "Self-Ownership, Freedom, and Autonomy," Journal of Ethics 2 (1998): 27-55; Daniel Attas, "Freedom and Self-Ownership," Social Theory and Practice 26 (2000): 1-23; Cécile Fabre, Whose Body is it Anyway? Justice and the Integrity of the Person (Oxford: Oxford University Press, 2006); Kasper Lippert-Rasmussen, "Against Self-Ownership: There Are No Fact-Insensitive Ownership Rights over One's Body," Philosophy and Public Affairs 36 (2008): 86-118.

${ }^{2}$ Lippert-Rasmussen, "Against Self-Ownership," 88.

${ }^{3}$ Fabre, Whose Body is it Anyway? 124.
} 
and about the degree to which our possession of certain physical objects would promote our autonomy or welfare. ${ }^{4}$ This makes rights over human bodies seem very much like rights over other kinds of objects. By contrast, most libertarians seem to assume that self-ownership is a fact-insensitive principle. They speak of persons as simply "coming into the world as" selfowners, whereas they think of property rights in extrapersonal resources as depending on facts about appropriation and transfer.

Interestingly, the asymmetry thesis has also been challenged from a libertarian perspective. According to Daniel C. Russell, the "self" of self-ownership extends beyond the body, so that the "owned self" of selfownership includes many things outside human bodies. ${ }^{5}$ This move apparently squeezes out attempts by so-called "left-libertarians" to defend an enforced egalitarian distribution of extrapersonal resources: such resources are part of our "selves" and are therefore just as stringently protected by rights as our bodies are. For this reason, Russell agrees that there is nothing special, as a matter of principle, about the human body: "the reason that the self extends to the body is the same reason that it also extends beyond the body." 6

My primary aim in this essay is to vindicate the fact-insensitivity of the principle of self-ownership, and with it, the asymmetry thesis: rights over one's body are morally distinct from rights over other objects because the former are not contingent on certain natural and social facts in the way that the latter are. Moral persons do indeed "come into the world as" selfowners. I believe that the abovementioned critics of self-ownership overlook this fact because they pay insufficient attention to the ontology of persons.

As I see it, self-ownership is most plausibly understood as based directly on the fundamental moral notion of respect for persons. The principle that each person ought to respect all other persons is itself fact-insensitive. If this principle directly entails the self-ownership of every person, then the validity of self-ownership is itself fact-insensitive. The argument supporting this entailment will be presented in Sections II, III, and IV of this essay. Section II prepares the terrain by clarifying the concepts of self-ownership, person, and "self," and the relations between them. Section III defends a particular conception of the person, according to which a person is more or less physically coextensive with an entire living organism. ${ }^{7}$ On the basis of this conception, we can say that the human body is special because

\footnotetext{
${ }^{4}$ On fact-sensitive versus fact-insensitive principles see G. A. Cohen, Rescuing Justice and Equality (Cambridge, MA: Harvard University Press, 2008).

${ }^{5}$ Daniel C. Russell, "Embodiment and Self-Ownership," Social Philosophy and Policy 27, no. 1 (2010): 135-67.

${ }^{6}$ Russell, "Embodiment and Self-Ownership," 157. A similar challenge might conceivably be formulated by advocates of the so-called "extended mind." See Richard Menary, ed., The Extended Mind (Cambridge, MA: MIT Press, 2010), for an anthology of recent writings.

${ }^{7}$ The reason for the qualifier "more or less" will become clear at the end of Section III.
} 
human persons are special. Section IV traces the relation between respect for persons and the bundle of rights that constitute self-ownership. Taken together, sections II-IV amount to a defense of the internal coherence of the idea of self-ownership as a basic right. ${ }^{8}$

A secondary aim of this essay, pursued in Section V, is to clarify the relations between respect, self-ownership, and freedom. The value of freedom-or autonomy, as it is sometimes called in this context-is itself often said to be grounded in respect for persons. Moreover, critiques of self-ownership often rest, as we have just seen, on the assumption that principles for the promotion or distribution of freedom are more basic than self-ownership. A full refutation of those critiques must therefore clarify how freedom fits into the alternative picture I am painting. I will argue that self-ownership and freedom do not stand in a hierarchical relation but are equally basic. Moreover, the two desiderata are compatible, at least in our world and in worlds similar to our own.

\section{Self-Ownership, Persons, and "Selves"}

Self-ownership can be defined in various ways. In the following discussion I shall assume a fairly standard interpretation according to which it covers the following set of rights: exclusive claims against nonconsensual interference with one's body and anything created through, or gained in exchange for, the exercise of its physical or mental powers; the claim not to be prevented from exercising those physical or mental powers in interaction with other objects over which one has claims against nonconsensual interference; the power to enforce, waive, or transfer the aforementioned rights; and immunities against the loss of any of the above rights. I shall leave open here the question of how "full" the above set of rights needs to be in order to constitute self-ownership. Perhaps the concept of selfownership has vague boundaries. But this fact need not be any more problematic than the vagueness of the boundaries of the concept of ownership in general. ${ }^{9}$

Self-ownership, in this standard sense, has been defended by deontological libertarians such as Robert Nozick, Murray Rothbard, and Eric Mack (commonly labeled anti-egalitarian or "right" libertarians), as well as Hillel Steiner, Michael Otsuka, and Peter Vallentyne (commonly labeled

\footnotetext{
${ }^{8}$ This defense does not take into account all relevant internal critiques. In particular, it does not address the argument that, exactly because the human body is special, we ought to resist the idea of property rights over bodies. See Anne Phillips, Our Bodies, Whose Property? (Princeton, NJ: Princeton University Press, 2013). I agree with Phillips in rejecting conceptions of the person that assimilate human bodies to extrapersonal objects. Her worry, however, is that such conceptions lead to the commodification of human bodies, whereas mine is that they misrepresent theories of self-ownership and set up straw men.

${ }^{9}$ See Jessica Flanigan's contribution to this volume, "Boundary Problems and SelfOwnership."
} 
egalitarian or "left" libertarians). ${ }^{10}$ Since it is reasonable to suppose that all of these theorists implicitly endorse the asymmetry thesis, the arguments of Lippert-Rasmussen, Cécile Fabre, and company should be understood as challenges to all of them.

In attempting to clarify the notion of self-ownership, it is easy to be misled into thinking that we need to clarify the notion of a "self." The term "self" might of course be treated as synonymous with "person," but it can also be used to refer to a person's sense of her place in the world, or to a particular object of introspection. In all of these cases, "a self" is a thing. In the term "self-ownership," by contrast, the word "self" does not refer to a thing, but serves merely to qualify the relation of ownership as a reflexive one. "1 "Self-ownership" is not like "home-ownership"; rather, it is like "self-determination," or "self-financing." Talk of home-ownership invites the question, "What is this thing, a home, that is owned?" whereas talk of self-ownership does not invite the question, "What is this thing, a self, that is owned?" If we do ask this question, we will then have to follow up with another question: "What, moreover, is the self that owns it?" We might then conclude that these two things-the owned self and the owning self-are nonidentical, in which case we will be denying the reflexivity of self-ownership. I prefer to avoid this mysterious implication and instead ask the more clear and fruitful question, "What is the thing that we call a person and that qualifies as a self-owner?"

What, then, is a person? In order to answer this question in a way that is charitable to the advocates of the standard notion of self-ownership, we should begin by asking what self-ownership itself presupposes about persons. On the standard notion, self-ownership encompasses rights over a whole body. As far as self-ownership on the part of human beings is concerned, that body is a human body. Therefore, if one endorses the standard notion of self-ownership while also recognizing that self-ownership is a reflexive relation, one is necessarily presupposing that a self-owning human person is coextensive with a whole human body. ${ }^{12}$

${ }^{10}$ Robert Nozick, Anarchy, State, and Utopia (New York: Basic Books, 1974); Murray Rothbard, The Ethics of Liberty (Atlantic Highlands: Humanities Press, 1982); Eric Mack, "Self-Ownership, Marxism, and Egalitarianism, Part I: Challenges to Historical Entitlement," and "SelfOwnership, Marxism, and Egalitarianism, Part II: Challenges to the Self-Ownership Thesis," Politics, Philosophy, and Economics 1 (2002): 75-108, 237-76; Hillel Steiner, An Essay on Rights (Oxford: Blackwell, 1994); Michael Otsuka, Libertarianism Without Inequality (Oxford: Oxford University Press, 2003); Peter Vallentyne, Hillel Steiner, and Michael Otsuka, "Why LeftLibertarianism Is Not Incoherent, Indeterminate, or Irrelevant: A Reply to Fried," Philosophy and Public Affairs 33 (2005), 201-15.

${ }^{11}$ Cohen, Self-Ownership, Freedom, and Equality, 211.

${ }^{12}$ For an argument along these lines, see Edward Feser, "Personal Identity and Self-Ownership," Social Philosophy and Policy 22 (2005): 100-125. The conception of the person that I shall defend is close to Feser's, although I resist his characterization of the person as consisting in "a composite of form and matter, soul and body" that allows for the survival of the soul "beyond the body's death" (p. 120). On the Strawsonian conception that I shall defend, there is no such asymmetry between mind and body, and neither is the person a composite; rather, the concept of a person is primitive with respect to those of mind and body. 
Not all human bodies are persons. In order for a body to qualify as a person, it must possess certain characteristics. It is widely accepted among deontological liberal theorists that the relevant characteristics consist in a set of agential powers: a person possesses the cognitive powers to identify ends, to discriminate between ends, to identify adequate means to ends, and to form plans, as well as the volitional power effectively to carry out such plans. It is also widely accepted among such theorists that persons have value in virtue of these characteristics. They have value in the sense of being a kind of object that appropriately elicits a certain kind of reaction. This reaction is normally characterized as one of respect, where respect consists both in an attitude and in certain resultant forms of behavior. I will return to this foundational notion of respect for persons in the next two sections. As I will argue there, it is because of the respect that is owed to a person that she automatically qualifies as a self-owner simply upon "coming into the world." I shall focus primarily on the human person, which is the only kind of existing person we are familiar with, and which comes into the world when a normal human being reaches a certain level of maturity in terms of development of the abovementioned agential powers. But this is not to deny that there can in principle be other kinds of persons.

I have said that the standard, reflexive notion of self-ownership presupposes a conception of the human person as coextensive with a whole human body. This conception, however, does not appear to be the most popular one in mainstream contemporary philosophy of mind. Most contemporary conceptions of the person seem to assume that I, a person, am something distinct from "my body" - perhaps an immaterial substance, or perhaps, as many contemporary neuroscientists claim, a material substance consisting in a brain, or perhaps just a bundle of perceptions, cognitions, and volitions supervening on a brain. On this view, "my body" is something that I "occupy," "inhabit," "control," or "use" in order to perceive the world and to act in it; ${ }^{13}$ I am connected in an intimate way to a human body, but I am not that body; rather, my body is something I have. There is a particular relation of possession between myself and my body, or between myself as mind and myself as body. This relation has yet to be specified adequately and therefore remains somewhat mysterious, but might, we are told, be clarified in the future by neuroscience. All such views can be characterized as "dualist" in some sense, even if the dualism in question is not necessarily one of mind and body in the classic sense. ${ }^{14}$

\footnotetext{
${ }^{13}$ The idea of persons as beings that "occupy" bodies is explicitly assumed in: Fabre, Whose Body is it Anyway? 15, 102; Christine Korsgaard, Creating the Kingdom of Ends (Cambridge: Cambridge University Press, 1996), 382; Steiner, An Essay on Rights, 232.

${ }^{14}$ Peter Hacker calls the materialist view espoused by some neuroscientists "brain-body dualism," because advocates of this view assign the same functions to the brain as Descartes assigned to the immaterial soul. See P. M. S. Hacker, Human Nature: The Categorial Framework (Oxford: Blackwell, 2007).
} 
Owing perhaps to the predominance of these conceptions of the person, many contemporary discussions of self-ownership seem to oscillate confusingly between acceptance of the reflexivity of self-ownership and the assumption of a form of dualism that seemingly contradicts it. Consider Lippert-Rasmussen's argument against the asymmetry thesis. Following Peter Vallentyne, Lippert-Rasmussen accepts that if a human person is identical only with her brain or her thoughts, then self-ownership entails only brain-ownership or thought-ownership, and the rest of the human body is then just one resource like any other, such as a car or a tract of land. ${ }^{15}$ The truth of this conditional statement presupposes the reflexivity of selfownership. Later on, he further claims that the idea of the person as consisting in a whole human body is indeed "implausible," citing, in his defense, the neo-Lockean thought experiment involving the transplant of a person's brain into another human body from which the brain has previously been removed. On the neo-Lockean view, the brain and its new body are fully continuous, as a person, with the brain and its old body. ${ }^{16}$ Lippert-Rasumssen takes this to imply that human persons are not whole human bodies. Presumably he is more sympathetic to the view that persons are brains, or to the view that they are sets of thoughts supervening on brains.

Now, if we start from this dualist view of the relation between a person and her body, or between a person-as-brain and the rest of her body, and we assume in addition that self-ownership is a reflexive relation, then we need hardly waste any more time refuting the standard notion of selfownership set out above, for the latter, when applied to human persons, affirms property in a whole human body, not just property in a brain or a set of thoughts. Nevertheless, the bulk of Lippert-Rasumssen's argument "against self-ownership" is devoted to undermining the ethically fundamental status of the claim that I own my whole body-where "my whole body" indeed appears to be something distinct from me. Thus, the conception of self-ownership against which the bulk of his argument is directed appears to be a nonreflexive conception.

A refutation of the asymmetry thesis that simply assumes such a nonliteral, nonreflexive conception of self-ownership is surely to some extent question-begging. If we assume that I am distinct from, and only contingently related to, "my body," then it will indeed follow naturally that the importance of "my body" to "me" is weaker than most advocates of selfownership seem to believe. It will indeed be unclear "why the mere fact that something is a part of one's body should in itself make a significant moral difference." 17

${ }^{15}$ Lippert-Rasumussen, "Against Self-Ownership," 90-91; Peter Vallentyne, "Critical Notice of G. A. Cohen's Self-Ownership, Freedom, and Equality," Canadian Journal of Philosophy 28 (1998): 609-29, at pp. 613-14n. For a more exhaustive argument along these lines see Feser, "Personal Identity and Self-Ownership,"secs. IV-VII.

${ }^{16}$ Lippert-Rasmussen, "Against Self-Ownership," 114n.

${ }^{17}$ Lippert-Rasmussen, "Against Self-Ownership," 115. 
Daniel Russell's argument in favor of an expanded "self" similarly seems to involve a form of dualism that implicitly contradicts the reflexivity of self-ownership. On the one hand, Russell holds that "one owns oneself" (not just one's self), and this suggests the reflexivity of self-ownership. ${ }^{18}$ On the other hand, he holds that "the self includes one's sense of practical and physical possibilities." The latter "obviously cannot be restricted to that part of the physical world within the boundary of one's skin."19 Rather, my sense of my practical possibilities, and hence my "self," is embodied in many of the external objects with which I interact as I lead my life. It is also embodied in the associates, friends, and loved ones with whom I interact socially. In short, "if my leg represents one set of possibilities of my embodied existence, then so too does my wife." ${ }^{20}$ Now, if my "embodied self" includes my loved ones, then our embodied selves overlap with one another. These embodied selves cannot be coextensive with our owned selves, for our owned selves cannot themselves overlap, unless we are prepared to accept-as Russell is not-that each of us is partly owned by other owning selves. How are we to fix the boundaries of the owning self? I can see only two nonarbitrary alternatives: either they coincide with the boundaries of the "fully embodied self," and therefore reach beyond those of the owned self; or they coincide with the boundaries of the person's body (or a part thereof), which Russell calls those of the "quasi-embodied self," and therefore fall short of those of the owned self. In either case the owned self and the owning self are not coextensive and self-ownership is not, after all, a reflexive relation.

If, as I have suggested, we concentrate on the notion of a person, rather than on a distinct notion of "the self" (or on more than one distinct notion of "the self"), we will see that the human body does after all have a special status in moral relations, because human persons have a special status and human persons are human bodies. We will then see the coherence and plausibility of the standard, reflexive notion of self-ownership. I now turn to the task of clarifying and defending this position.

\section{The Physical Confines of the Person}

The conception of the person that best makes sense of the standard, reflexive notion of self-ownership is an anti-dualist conception of the sort defended by P. F. Strawson and P. M. S. Hacker. ${ }^{21}$ According to Strawson, any predicate applicable to a person understood as a subject of experience is also applicable to a physical body - in the cases known to us, to the physical

\footnotetext{
${ }^{18}$ Russell, "Embodiment and Self-Ownership," 152.

${ }^{19}$ Russell, "Embodiment and Self-Ownership," 141.

${ }^{20}$ Russell, "Embodiment and Self-Ownership," 142.

${ }^{21}$ P. F. Strawson, Individuals. An Essay in Descriptive Metaphysics (London: Methuen, 1959), chap. 3; Hacker, Human Nature.
} 
body constituting a normal human being. "[A] necessary condition of states of consciousness being ascribed at all is that they should be ascribed to the very same things as certain corporeal characteristics, a certain physical situation etc." 22 In this sense, the concept of the person is "primitive" - that is, not analyzable as a compound of two more basic kinds of entity consisting in "a particular consciousness and a particular human body." 23

\section{A. The body I am versus the body I have}

Hacker has further refined this anti-dualist conception of the person in such a way as to clarify the difference between "the body I am" and "the body I have." ${ }^{24}$ A normal human person is a biological organism that possesses, and exercises, various cognitive, perceptual and volitional powers. This organism is literally the body that I am. It is quite another thing to refer to the body that I have. There is no harm in talking of a human body as something I "have," as long as we recognize that this is merely a façon de parler. It is a way of speaking about the corporeal characteristics of the person that I am. ${ }^{25}$ This is what we really mean when we say that a person "has a beautiful body," that she "has a powerful body," and so on. "My body," in this sense, is not the body that I am: I, an organism, can feel a pain and cry out; but "my body," understood as a set of corporal properties, does not feel pain or cry out, for properties do not feel pain or cry out. ${ }^{26}$ If I say "I have a powerful body," what I mean is that I, an organism, have the corporeal property of being powerful. Thus, talk of "my powerful body" should not be taken to imply that there is a thing, consisting in a powerful body, that is distinct from me.

We normally speak of an organism as having a body only in a limited range of cases: trees and oysters are organisms, but we do not talk about "a tree's body" or "an oyster's body"; we do, on the other hand, speak of an organism as "having a body" when it is appropriate also to speak of it as "having a mind." 27 However, speaking of an individual as "having a mind" is, no less than speaking of it as "having a body," only a façon de parler - a way of referring to the set of mental powers that a certain kind of organism possesses and exercises. The concept of the person is indeed "primitive relative to the concepts of a person's mind and of a person's body." 28

22 Strawon, Individuals, 102 (emphasis added).

${ }^{23}$ Strawson, Individuals, 105.

${ }^{24}$ Hacker has also taken issue with Strawson's account on some points, in particular claiming that it contains a residue of dualism. See Peter Hacker, "Strawson's Concept of a Person," Proceedings of the Aristotelian Society 102, no. 1 (2002): 21-40.

${ }^{25}$ Hacker, Human Nature, 277.

${ }^{26}$ Hacker, Human Nature, 274-76.

${ }^{27}$ Hacker, Human Nature, 270-74.

${ }^{28}$ Hacker, “Strawson's Concept of a Person," 25 (emphasis added). 
Neither, on Hacker's conception, should the body that I am be confused with my brain, for I have many properties that are not shared by my brain: I observe, talk, calculate, walk, and run, but my brain does not do any of these things; I have a brain, but my brain does not. ${ }^{29} \mathrm{My}$ brain is an organ, whereas I am an organism. As an organ my brain is a necessary part of the organism that I am, but it is a mistake to suppose that the properties of an object apply automatically to a part of that object, however essential that part might be to the functioning of the whole. The body that I am is a substance that includes my brain and extends from my brain to the outer reaches of the biological organism that sustains it-that is, a substance that extends as far as my skin. I am neither distinct from a living organism nor a part of that organism. ${ }^{30}$

Hacker is skeptical about the verdicts reached by neo-Lockeans in science-fiction cases involving brain transplants. Perhaps the most that can be said about such cases is that, if they were a widespread reality, our concept of a person would be much less useful than it is. ${ }^{31}$ However, we need not take a stance on this controversial issue in the present context, for there is a relevant distinction to be made between the criteria establishing what I am and the criteria establishing my persistence over time. ${ }^{32}$ Let us assume that, if person $B^{\prime}$ s brain is removed, and person $A^{\prime}$ s brain is transplanted into the brainless body of person $B$, the resulting person-call it $A B$-is indeed psychologically continuous with $A$ and not with $B$ (who, as a result, is either dead or has continued to live thanks to another brain transplant into a third body). Would this fact make $A B$ the same person as $A$ ? We might answer in the affirmative if we hold, controversially but not absurdly, that none of the physical parts of a particular person other than her brain are essential to the persistence of that particular person over time. ${ }^{33}$ We can transfer body parts to $A$ without saying that $A$ thereby becomes a different person, just as we can substitute one or more of the legs of our dining room table without saying that it becomes a different table. None of this contradicts the claim that, after the brain transplant, the outer physical confines of the person in question (that is, $A B$ ) are the same as what used to be the outer physical confines of $B$. What we should not say is that, after the transplant, $A$ survives "in $B$ 's former body," for this

\footnotetext{
${ }^{29}$ In this paragraph I am freely paraphrasing claims made in chapters 9 and 10 of Hacker, Human Nature.

${ }^{30}$ On the confusion of the properties of a part with those of the whole, which Hacker calls the "mereological fallacy," see M. R. Bennet and P. M. S. Hacker, Philosophical Foundations of Neuroscience (Oxford: Blackwell, 2003), chap. 3.

${ }^{31}$ Hacker, Human Nature, 301-310.

32 On this point see Eric T. Olson, What Are We? A Study in Personal Ontology (Oxford: Oxford University Press, 2007), 17-18. Most discussions of "personal identity" have concentrated on the latter criteria, with apparent knock-on effects in political philosophy. See e.g., Fabre, Whose Body is it Anyway? 12-16, 111.

${ }^{33} \mathrm{I}$ am indebted here to the helpful discussion in Victor Tadros's contribution to this volume, "Ownership and the Moral Significance of the Self."
} 
claim makes sense only on the false assumption that persons are brains or mental states and that persons "occupy" bodies.

I will not look any further for theoretical reasons to endorse the Strawson-Hacker conception of the person. Instead, and more to the point in the present context, I wish now to point to some compelling practical reasons for adopting it.

\section{B. Basic actions versus nonbasic actions}

In practical philosophy we start from the premise that persons exist and interact. Interactions are made up of actions, and all actions involve movements of physical bodies - that is, of objects that are extended over time and space. (More precisely, all actions involve either physical movements or the omission of such movements-that is, actual or hypothetical resistance to some force that would otherwise bring about a physical movement. For convenience I will assume that the expression "physical movements," when referred to actions, also covers such omissions).

Following the pioneering work of Arthur Danto, philosophers of action standardly distinguish between "basic" actions and "nonbasic" actions. ${ }^{34}$ A nonbasic action is an action we perform by performing another action. A basic action is an action we perform directly, rather than by performing another action. As Danto famously claimed, "if there are any actions at all, there are basic actions," for the "by-relation" cannot be traced back indefinitely. ${ }^{35}$

Now, unless persons are immaterial substances, their basic actions, no less than their nonbasic ones, must involve physical movements. Persons possess, among other things, agential powers - the power to perform actions. As performers of basic actions, persons must be considered self-moving beings. It follows that their basic actions are movements of themselves. In the case of humans, moreover, we have reason to see such bodily movements as extending as far as the outer confines of the human body. Consider the following example: I turn the screwdriver by rotating my hand, but I do not rotate my hand by doing something else. After all, there is a clear answer to the question, "What did you do in order to make the screwdriver turn?" The answer is: I rotated my hand. By contrast, there is no such clear answer to the question, "What did you do in order to rotate your hand?" Rather, it is natural to retort, "I just did it." I might provide a scientific explanation of "how" I rotated my hand that refers to neuron firings and muscle contractions, but that will be a thirdpersonal causal account, not a first-personal agential account of the sort

${ }^{34}$ Arthur C. Danto, Analytical Philosophy of Action (Cambridge: Cambridge University Press, 1973).

${ }^{35}$ Arthur C. Danto, "Basic Actions," in Alan R. White, ed., The Philosophy of Action (Oxford: Oxford University Press, 1968), 45. 
that I supply when I say how I turned the screwdriver. My rotating of my hand is therefore a basic action, whereas my turning of the screwdriver is a nonbasic action. (This conclusion is compatible with the fact that we sometimes turn screwdrivers without thinking about how we are doing so. Someone might say "I just did it" in reference to the turning of the screwdriver. ${ }^{36}$ Nevertheless, if that person is forced to reflect on the matter she will normally be able to give a first-personal explanation referring to the fact of her rotating her hand.)

The claim that human basic actions are coextensive with human bodily movements has not gone uncontested. Some-called "volitionists"—have claimed that all basic human actions take place somewhere inside the human body, and that their physical components do not therefore extend as far as the skin. ${ }^{37}$ There are indeed causal chains of events within the body that start with acts of the will and include muscle contractions. If such a chain were interrupted at some point, owing, for example, to the paralysis of a limb, the act of will would still take place. Therefore, it is said, all basic actions take place before human bodily movements do.

I believe we should resist this suggestion, for it takes us down a slippery slope toward a conception of agents as immaterial substances. As Danto points out, if we assume that acts of the will are themselves physical events, then such acts also take time and consist in causal chains. Paralysis could set in at any point in such a chain too. Once we have shrunk our "selves" to the boundaries of our cranial circumference, then, why not shrink them further? We need some nonarbitrary place at which to stop, in order to establish the distinction between our physical selves and that which "we" cause. "Since we have at last to make this distinction, why not have made it sooner before we were driven by an inexorable logic away from the boundaries we may rightfully consider ours: those of the entirety of our bodies with which we actively perform?"38

The rhetorical question just cited might plausibly be interpreted as motivated by a sense of respect for persons. In previous work I have claimed that a respect-based morality-at least within the confines of a political conception of justice-prescribes treating persons as "opaque." 39 "Opacity respect" — as I have called it—involves the conferral of a kind of "outward dignity" on a being that is perceived to have at least a minimum of certain agential capacities. Conferring this outward dignity involves taking the being's integrity as a given fact, where "integrity" is meant

\footnotetext{
${ }^{36}$ See Eric T. Olson, The Human Animal: Personal Identity Without Psychology (Oxford: Oxford University Press, 1997), 146.

${ }^{37}$ See Hugh McCann, "Volition and Basic Action," Philosophical Review 83 (1974), 451-73; Jennifer Hornsby, Actions (London: Routledge and Kegan Paul, 1980). For an overview, see Carlos J. Moya, The Philosophy of Action: An Introduction (Cambridge: Polity Press, 1990), chap. 2.

${ }^{38}$ Danto, Analytical Philosophy of Action, 78.

${ }^{39}$ Ian Carter, "Respect and the Basis of Equality," Ethics 121 (2011): 538-71.
} 
in the sense of wholeness and completeness. One confers this kind of dignity by ensuring that one's practical reasoning, about how to interact with another agent, does not include any considerations that presuppose "looking inside" that agent or dismantling it into its component parts or conceiving of it merely as so many reactions to physical stimuli. One instead adopts an external perspective and takes the agent as given. In my previous work I applied this notion of opacity respect to a person's psychological features-in particular, to her agential capacities understood as powers of reason-claiming that to respect a person in the relevant way is to refrain from acting on the basis of assessments of the degrees to which she possesses such capacities beyond a minimum qualifying threshold. It seems to me, however, that we also have reason to apply the notion of opacity respect to the extended being that has the agential capacities in question. In other words, we respect a person if the ways in which we reason about how to interact with her involve recognizing her outer physical confines as a complete organism rather than mentally dismantling her into so many causal chains or bundles of volitions or perceptions.

This account of respect for persons-as-agents supports Danto's view of basic actions as human bodily movements. Successively removing the outer reaches of the causal chains within a human body is like successively removing the outer layers of an onion. There is no nonarbitrary place at which to stop, unless one is happy to continue until there is nothing left of the onion. Analogously, there is no nonarbitrary place to stop removing the outer reaches of the causal chains, unless one is happy to arrive at the idea of "the agent" as an immaterial substance with mysterious causal powers over the material world. Conferring dignity on a person, understood as an extended substance with a set of agential powers, involves treating her as having a kind of physical integrity that rules out this kind of conceptual dissection or dismantlement. For practical reasons, we ought indeed to think of the concept of the person as "primitive" in Strawson's sense.

At this point, the following objection might be raised. If our notion of respect for persons is itself supposed to be helping us, in this virtuously circular way, to clarify how we understand the physical confines of persons, and if we respect persons in virtue of their being agents, ought it not to follow that those parts of a body that a person cannot move directly, such as her internal organs, are not parts of the being to which we owe respect-that is, that they are not parts of "the agent"? Should we say that my kidneys are not a part of $m e$, in the way that my nervous system and limbs are a part of me, given that the physical movements that constitute my basic actions involve causal chains linking only those structural parts of my body, while the functioning of organs like the kidneys and pancreas are merely necessary conditions for the effectiveness of such causal chains, in the same way as the oxygen surrounding me is? This striking claim, which happens to be made by Danto himself, would certainly be damaging 
for the standard notion of self-ownership. ${ }^{40}$ However, we do not need to accept this line of reasoning in the present context. According to the notion of respect that I am assuming here, and to which I shall return in the next section, respect is due to agents, and agents are physically extended beings with certain cognitive, volitional, and physical powers. Agents are not those powers, but are beings that possess those powers. Given this distinction between agents and their powers, we are under no constraint to identify an agent only with those parts of a physical being the movements of which count as exercises of its powers. We can just as well say that the agent is a physical being that can and does perform basic actions.

The above discussion does not, perhaps, establish all of the necessary and sufficient conditions for being a physical component of a person, but it does come fairly close. Being a part of a human organism is certainly a sufficient condition. It is perhaps not a necessary condition, given that artificial body parts might so qualify. In the latter case, the criterion of basic action might help us decide which objects count as parts of the person and which do not: some kinds of artificial body parts, such as functioning artificial eyes or technologically sophisticated artificial limbs that are connected directly to the person's nerves and muscles, might be physical components of basic actions, and in this sense qualify as a part of the person. Being a physical component of basic actions is again not a necessary condition for being a part of the person, as we have just seen in reference to internal organs. The disjunction of the two conditions, on the other hand, does seem intuitively to be a necessary condition. On this view, a detachable prosthesis with which one can perform only nonbasic actions does not qualify as a part of the person. This is not to deny, on the other hand, that the violation of a person's right over such a prosthesis might, for other reasons, be more serious than the violation of her right over some other object to which she stands in a less intimate relation.

If we conceive of persons in the above way, does the notion of respect for persons directly imply anything as specific as the bundle of rights constituting self-ownership? The fact of "having a body" might be a peculiar trait of persons, but it is not to be confused with the normative relation of ownership. ${ }^{41}$ If we are to vindicate the asymmetry thesis, that normative relation now needs to be clarified.

\section{The Relation between Respect for Persons and SELF-OWNERSHIP}

What sort of behavior is appropriate on the part of someone who adopts the attitude of respect for persons? Since I have assumed that persons are

${ }^{40}$ Danto, Analytical Philosophy of Action, 141. See also Olson, The Human Animal, 148. Lippert-Rasmussen raises this point as an objection in "Against Self-Ownership," 111.

${ }^{41}$ Hacker, Human Nature, 280; Attas, "Freedom and Self-Ownership," 17. 
due respect in virtue of their agential powers, a reasonable place to start is with the quasi-Kantian maxim that one should always treat them as ends in themselves. Let us consider how this maxim can be fleshed out in such a way as to provide a basis for self-ownership. ${ }^{42}$

Treating persons as ends in themselves is often taken to mean "not treating them merely as means to one's ends." What, then, is it to treat a person merely as a means? Some have interpreted this idea as ruling out coercion and other kinds of social power. I consider such a view to be either too vague or overinclusive. The prohibition on "using merely as a means" might nevertheless have a clearer, if more limited, application if we understand it as a prohibition on the physical use of the body that is a person, without her consent and merely as a means to one's own ends, where such use involves direct, nonconsensual physical intervention altering the person's location or composition.

On a broader understanding of the ideal of treating persons as ends in themselves, which includes but is not limited to the above account, what is prescribed is that we treat persons in ways that are appropriate in light of their qualifying as the points of origin of ends-that is, in light of their being individuals that possess and exercise agential powers. We can fail to treat a person in this way while nevertheless avoiding treating her as a means to our own ends, for we can intervene physically on her body for the sake of her own ends, of which we claim to have a superior understanding. This would amount to a form of paternalistic intervention. We can also fail to treat a person in the appropriate way (in light of her being a point of origin of ends) simply by placing certain external constraints on her available actions, either in our interests or in hers. In such cases we will be engaging in a disrespectful restriction of the person's freedom -a point to which I shall return in the next section.

One might discuss at length how this characterization of respect for persons can be taken to generate exactly all of the rights that are normally seen as covered by the standard notion of self-ownership. Still, a fairly clear, prima facie case can be made for the self-ownership of persons by considering how respect for persons, on the above characterization, implies certain broadly defined sets of normative claims, liberties, immunities, and powers.

Consider first the enforceable normative claim against others' nonconsensual physical use of oneself or any part of oneself, where "oneself" is interpreted along the lines set out in the previous section. This normative

${ }^{42}$ I call the maxim "quasi" Kantian, because Kant himself affirmed that one should treat humanity, which is to say, one's own and others' rational agential powers, as an end in itself. Cohen, Attas, and Fabre, in the works cited above, appeal to Kant in their criticisms of the derivation of self-ownership from the idea of treating persons as ends. For a partial response to Cohen, see Eric Mack, "Self-Ownership, Marxism, and Egalitarianism, Part II," 265-66. See also Robert S. Taylor, "A Kantian Defense of Self-Ownership," Journal of Political Philosophy 12 (2004): 65-78. 
claim is straightforwardly entailed by the prohibition on using persons as mere means.

Fabre has argued that I can make physical use of a person, forcing her to provide services or even forcibly extracting certain of her live body parts, and yet avoid treating her merely as a means, as long as I continue to recognize her status as a person and intentionally leave her a measure of freedom to carry out her most important projects. ${ }^{43}$ Such an interpretation of the quasi-Kantian maxim is implausibly lax. As I interpret it, the idea of treating "merely" as a means refers to the means-ends reasoning motivating the particular action in question. One cannot absolve oneself of the accusation of treating someone merely as a means simply by performing other actions (or omissions) that do not treat her as a means. The point of adding the qualification "merely" is not to permit such behavior, but to permit a particular action that has mixed motives. Many forms of voluntary cooperation fall into the latter category.

Consider next a person's claim not to be prevented from performing any basic action involving the occupation of space over which that person also has a claim against nonconsensual interference. This claim is often taken to protect a kind of normative liberty. Strictly speaking, however, it does not entail anything as strong as a moral permission to perform any such basic action. The point, rather, is that even if one condemns a specific basic action of a person as morally wrong, one's treating that person as a point of origin of ends nevertheless involves one's recognizing and respecting her claim not to be prevented from performing that action, as long as that action does not violate the just claims of others. ${ }^{44}$ Self-ownership includes such a "right to do wrong."

Consider, third, the normative immunity against others' nonconsensually canceling or transferring any of the above claims or liberties. This immunity follows naturally from the respect-based rationale for those same claims and liberties. For the power of others to cancel any such rights over oneself would expose one to the possibility of being used by others or of being subject to paternalist invasions of one's physical confines.

Consider, finally, the normative power of the person to enforce, waive, or transfer such claims or liberties. This power is more controversial in certain cases, but can again be taken in general to follow from the anti-paternalist idea of treating persons as the points of origin of ends. Individuals pursue ends through the performance of moral and legal acts-permitting, prohibiting, donating, buying and selling-no less than through the performance of physical actions.

These considerations point to the fact-insensitivity of the principle of self-ownership. "Each person should respect every other person" is a fact-insensitive principle, and that principle, in conjunction with the

${ }^{43}$ Fabre, Whose Body is it Anyway? 113.

${ }^{44}$ See Taylor, "A Kantian Defense of Self-Ownership," 67. 
Strawson-Hacker conception of the person, can be understood as directly entailing the principle of universal self-ownership as standardly defined. Only if we think of persons as contingently related to "their bodies," as Lippert-Rasmussen and many others appear to, will self-ownership depend on facts about how persons relate to their bodies, and/or on facts about the nature of the set of property rights over human bodies and other resources that will prove optimal in terms of the independently justified goal of promoting people's freedom or autonomy or need-satisfaction. As Hacker has made clear, however, "a person's body" is not an object but is the set of corporeal properties of an object. The latter object is a person, and an object does not stand in a relationship to its own properties. ${ }^{45}$

On this basis, pace Lippert-Rasmussen, Fabre, Russell, and others, we can also now see the plausibility of the asymmetry thesis implicitly endorsed by advocates of the standard notion of self-ownership. If the above reasoning from respect to self-ownership goes through, one's ownership rights over a particular body - that is, over oneself-are indeed intrinsically different, morally speaking, from one's ownership rights over a particular car or house or tract of land. While the former are directly entailed by respect for persons, the latter are at most entailed by respect for persons together with contingent facts about people's physical locations, their appropriations, and their transfers-facts, to paraphrase Nozick, about how people choose and are chosen. Persons do indeed come into the world as selfowners, but they do not come into the world as owners of particular extrapersonal resources. Thus, while property rights in one's own person are fact-insensitive, property rights in extrapersonal resources are factsensitive. This difference is intrinsic to the kinds of property rights in question, and it is clearly of moral relevance. Therefore, the asymmetry thesis is well-founded.

Finally, it is worth noting that a property right can be understood either as a specific title over an object or as a general right "to hold property." The latter kind of right is a meta-right - that is, the right of a person to acquire rights over specific objects. The argument I have presented above refers only to property rights understood as specific titles. In this sense, it compares like with like: all the property rights in play in my argument, whether over human bodies or over extrapersonal resources, are specific titles over specific objects. Now it might be suggested that the meta-right to become an owner of extrapersonal resources is, by contrast, fact-insensitive. Since this suggestion leaves intact my argument about specific titles over bodies and extrapersonal resources, I can remain agnostic about its validity. This said, I do think that there are reasons to be skeptical about the fact-insensitivity of such a meta-right. One such reason is that the justification of property rights in extrapersonal resources, unlike the justification of rights in oneself, does seem to depend on the contingent relation between the protection of such

${ }^{45}$ Hacker, Human Nature, 283-84. 
rights, on the one hand, and respect for the more basic right of persons to a measure of freedom or autonomy, on the other. ${ }^{46}$

\section{The Relation between Self-Ownership and THE Right to FREEDOM}

According to many of its critics, self-ownership is at best justified by reference to a more basic principle of freedom or autonomy. I have rejected that claim and instead grounded self-ownership directly in respect for persons. Nevertheless, freedom and autonomy are themselves often taken to be grounded in respect for persons. How, then, does freedom or autonomy fit into the picture, if not in the way hypothesized by the critics of self-ownership? If self-ownership is not itself grounded in the promotion or just distribution of freedom or autonomy, what is the true relation between these different desiderata, and are they always compatible?

I shall focus here on the principle of equal freedom, and assume, along left-libertarian lines, that a right to equal freedom entails the right to an equal share of resources at the beginning of one's life as an agent. ${ }^{47}$ The truth of this assumption is independent-at least roughly speaking-of whether one conceives of freedom in the pure negative sense (that is, as the absence of physical prevention of hypothetical actions) or, alternatively, as the presence of options identified on the basis of a person's abilities to act. ${ }^{48}$ Autonomy is often understood in this context simply as the availability of options, and to this extent my remarks will apply to a principle of equal autonomy no less than to one of equal freedom. ${ }^{49}$ They will also apply to alternative egalitarian provisos, such as "equal opportunity for welfare." 50

Those critics of self-ownership who adopt a deontological perspective seem to have in mind that the morally basic notion of respect for persons can at most provide a justification of self-ownership via the right to freedom:

\section{Respect for persons $\rightarrow$ The right to freedom $\rightarrow$ Self-ownership}

The basic idea here seems to be that self-ownership is a form of property right, and property rights, within a libertarian framework, must

\footnotetext{
${ }^{46}$ I have explored this relation in A Measure of Freedom (Oxford: Oxford University Press, 1999), chap. 9.

${ }^{47}$ See Steiner, An Essay on Rights, chaps. 2, 6.

${ }^{48}$ On the meaning of "roughly speaking" in this sentence, see Carter, A Measure of Freedom, sec. 10.3. I am assuming here that the relevant conception of freedom is not "moralized" or "rights-based" (A Measure of Freedom, secs. 3.1, 8.5).

49 See Cohen, Self-Ownership, Freedom, and Equality, 236, and Fabre, Whose Body is it Anyway? 34.

${ }^{50}$ Otsuka, Libertarianism Without Inequality, chap. 1.
} 
themselves be based on a more fundamental principle according to which everyone is entitled to a measure of freedom-for left-libertarians, an equal measure-where this entitlement to freedom is in turn based on the notion of respect for persons. Such appears to be the view of Hillel Steiner. Although he does not refer explicitly to respect for persons as grounding basic rights, Steiner sees the principle of equal freedom as justifying two kinds of original property right: self-ownership, and an equal share of initially unowned things. ${ }^{51}$

According to the critics of self-ownership, however, recognizing the whole bundle of rights entailed by self-ownership is not, as a matter of contingent fact, always the best way, and is certainly not the only way, to promote or preserve equality of initial freedom. For example, consistent with equal quotas of overall freedom, the able-bodied could be made to compensate the infirm with additional resources through forced labor or through the involuntary transfer of body parts. Thus, in the name of equal freedom, we could forcibly transplant one eye from a person with normal vision to a blind person. ${ }^{52}$

As I see it, the right to an equal measure of freedom is indeed based on the more fundamental notion of equal respect for persons, ${ }^{53}$ and does not itself entail self-ownership. If the line of reasoning pursued in the previous section is accepted, however, we should conclude that equal freedom and self-ownership are on a par: both are based directly on the notion of respect for persons. In this case, the proper relations of derivation between respect for persons, the basic right to a measure of freedom, and self-ownership, are more correctly represented as follows:

\section{$\nearrow^{\text {Self-ownership }}$}

Respect for persons

The right to freedom

I submit, further, that we should also deny the converse of Steiner's claim: not only does the right to a measure of freedom not logically entail self-ownership; self-ownership similarly fails to entail the right to a measure of freedom in the use of extrapersonal resources. Eric Mack has defended the latter entailment: according to him, "a person's selfownership can sometimes be trenched upon by her interaction with the

${ }^{51}$ Steiner, An Essay on Rights, 231-36.

${ }^{52}$ Cohen, Self-Ownership, Freedom, and Equality, 70.

${ }^{53} \mathrm{I}$ am assuming here that the kind of respect in question - "recognition respect" - is necessarily equal. See Carter, "Respect and the Basis of Equality." 
world being blocked." Thus, in a state of nature in which all extrapersonal objects are unowned, I will violate your self-ownership if I exercise my normative liberties in ways that deny you the possibility of moving around freely: "If you simply block my movement by standing still at the narrowest point in the unowned slot canyon I am hiking though, you trench upon my self-ownership." ${ }^{54}$ To my mind this confuses the violation of a person's ownership rights in herself with the violation of her right to a measure of freedom. A car without fuel or access to roads is useless-at least to anyone who uses cars only for the purpose of travel. Nevertheless, ownership of a car does not, all on its own, entail ownership either of the space it is occupying or of the fuel needed to drive it out of that space and into another. Similarly, my ownership of myself does not, all on its own, entail liberty rights the exercise of which makes use of extrapersonal resources. Ownership entails, among other things, (i) claims that others not use the object in question (a car, a human body), together with (ii) a claim not to be prevented from performing actions that involve movements of that object in combination with movements or occupyings of other objects or space, respectively, over which one has claims of noninterference. These last claims do not in themselves entail any claims that others not use unowned objects or space in ways that block one's actions.

Of course, no sane deontological liberal, whether of the right or the left, recognizes the right of self-ownership without recognizing an accompanying claim to a measure of freedom interpreted in one way or another. This is because deontological liberals believe in respect for persons. But to favor both the basic right of self-ownership and the basic right to a measure of freedom is not to say that one entails the other or contains elements of the other, and neither is it to affirm that the right of selfownership must itself be conceived as "effective" 55 or "substantial,"56 rather than "merely formal."

It might now be objected that I have effectively abandoned the asymmetry thesis. Does that thesis not imply that my property in myself is different from my property in my car? If self-ownership does not on its own guarantee even a minimal measure of physical freedom in the ways one interacts with the extrapersonal world, what is the point of affirming self-ownership? The answer to this question is already implicit in the abovementioned objections to the idea of basing self-ownership on equal freedom: there are many alternative ways of realizing equal freedom, not all of which involve fully respecting people's property

\footnotetext{
54 Mack, "Self-Ownership, Marxism, and Egalitarianism. Part II," 246. Mack seems nevertheless to endorse a position closer to mine in "The Natural Right of Property," Social Philosophy and Policy 27, no. 1 (2010): 53-78, see esp. 60, 69-71.

${ }_{55}$ Cohen, Self-Ownership, Freedom, and Equality, chap. 4.

${ }^{56}$ Mack, "Self-Ownership, Marxism, and Egalitarianism. Part II," 244.
} 
rights in themselves. It follows that the asymmetry thesis has normative bite whenever we are faced with alternative ways of delineating people's original property rights in conformity with the principle of equal freedom, some but not all of which are compatible with self-ownership. The asymmetry thesis implies that self-ownership is a special kind of original property right and has priority when it comes to delineating the set of people's original property rights in a way that also respects people's basic right to an equal measure of freedom.

Understood in this way, the asymmetry thesis is exactly what motivates the left-libertarian to focus exclusively on normative limitations on the appropriation of extrapersonal resources, for these limitations represent a self-owner-friendly way of delineating original property rights in favor of the naturally disadvantaged. Self-ownership, for the left-libertarian, is an independently justified constraint on the way in which equal initial freedom may be realized. Given that constraint, taxation is aimed only at those who have violated others' rights to an initially equal measure of freedom by appropriating extrapersonal resources beyond the specified limit. This way of enforcing an equal-freedom proviso does not amount to taxing people's talents or conscripting their labor.

What of situations in which there is no way to realize equal freedom without infringing self-ownership rights? It seems to me that such a conflict will arise only in worlds very different from our own-for example, in a world in which the natural inequalities between different persons' abilities, or the values of their body parts, are very much greater than the inequalities that currently exist, and the physically disabled outnumber the better endowed, and/or extrapersonal resources are much more scarce and are therefore insufficient to provide compensation to the less wellendowed. As long as such extraordinary circumstances do not obtain, the disabled can be assigned sufficient extrapersonal resources to purchase the services of others, or perhaps even some of their body parts, through voluntary exchange..$^{57}$ Should those extraordinary circumstances obtain, however, it might indeed turn out to be contingently true that the realization of a right to equal freedom would require compulsory transfers that would infringe the self-ownership rights of the better endowed, in which case either self-ownership or equal freedom must give way. It is difficult to say what left-libertarianism would prescribe in a world so different from our own. ${ }^{58}$ The asymmetry thesis does not itself entail the priority of selfownership in such circumstances, for that thesis involves a comparison only of two kinds of property right; it does not involve a comparison of

${ }^{57}$ See Otsuka, Libertarianism Without Inequality, 33-35.

58 The fact that such a world is very different from our own holds true despite the fact that extensive opportunities for genetic enhancement are likely to lead, in our own unjust world, to enormous interpersonal ability differentials. If such technological opportunities exist, they can be distributed equally without violating self-ownership. 
the basic right of self-ownership and the basic right to an equal measure of overall freedom. But this problem takes us beyond the scope of the current investigation. What matters for present purposes is that the possibility of such a world does not contradict my interpretation of self-ownership as a fact-insensitive principle. What it does show is that the principles entailed by the fundamental notion of respect for persons are not only plural but are also potentially conflicting. It is itself a fact that two fact-insensitive principles can conflict, if pluralism is true. But this further fact does not make the principles themselves fact-sensitive.

\section{CONCLUSION}

In this essay I have defended the coherence of the idea that persons come into the world as self-owners simply because persons are owed respect as such. This idea contrasts with the view, often advanced by critics of self-ownership, that the notion of self-ownership rests on shaky ground because any appeal it has must, at best, derive from the more basic values of freedom or autonomy. I have diagnosed the critics' view as resting on an implicit dualist assumption to the effect that persons are distinct from their bodies and stand in contingent relations to them. Such assumptions lead them to think of "our bodies" as a kind of resource that is in principle no different from other kinds of resource. I have defended an alternative, anti-dualist conception of the person. If we conceive of persons in this alternative way, we shall see that bodies are special because persons are bodies and persons are owed respect. If this alternative account is correct, then critiques of self-ownership based on the value of freedom or autonomy are off-target, or are at least incomplete, requiring a clearer and more thorough treatment of the concept of a person.

I have suggested that respect for persons entails not only self-ownership but also the requirement to distribute freedom equally among persons. Moreover, as the critics of self-ownership have pointed out, equal distributions of freedom can infringe self-ownership rights. We have also seen, however, that freedom can be equalized in ways that respect self-ownership rights, at least in our world and in worlds similar to our own. As a result, the fact-insensitive principle of self-ownership can play an important constraining role in respect-based theories of distributive justice.

Political Philosophy, University of Pavia 